http://ijeds.ppj.unp.ac.id/index.php/IJEDS

\title{
Practicality of Authentic Instruments Computer Competency Assessment for Students of Vocational High School
}

\author{
* Elsa Firdianis ${ }^{1}$, Ambiyar², Wakhinuddin³, M. Iksan Ardiyansyah ${ }^{4}$, Yumn \\ Jamilah $^{5}$ \\ ${ }^{1}$ Magister Student of Faculty of Engineering, Universitas Negeri Padang \\ ${ }^{2}$ Mechanical Engineering Lecture, Faculty of Engineering,Universitas Negeri Padang \\ ${ }^{3}$ Automotif Engineering, Lecture, Faculty of Engineering, Universitas Negeri Padang \\ ${ }^{4}$ Magister Student of Faculty of Engineering, Universitas Negeri Padang \\ ${ }^{5}$ Magister Student of Faculty of Engineering, Universitas Negeri Padang \\ Email: cha.firdianis@gmail.com
}

\begin{abstract}
This study aims to develop authentic instruments in the assessment of Digital simulations to measure student learning skills that are practical and effective. This research uses Research and Development with ADDIE development models. Through the stages of analysis (analysis), design (design), development (development), implementation (implementation), evaluation (evaluation). The research subjects were students of class X SMK Negeri 05 Padang, digital simulation subjects. The research data was obtained through validation instrument sheets, practical questionnaires, and observations. The practicality test results show that the authentic assessment that was developed was very practical with the percentage of practicality of teachers on lesson plans being $88.3 \%$ and authentic assessments at $82.3 \%$. This developmental research produced an authentic practical and effective assessment instrument that can be used by teachers in assessing students' skills in school in the learning process.
\end{abstract}

Keywords : Authentic Assessment, Practicality, Effectiveness

\section{INTRODUCTION}

Assessment is the process of gathering and processing information to measure the achievement of student learning outcomes. The assessment of learning outcomes based on education is carried out to monitor the process, learning progress, and continuous improvement in student learning outcomes. Furthermore, the assessment of 


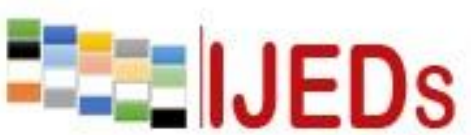

http://ijeds.ppj.unp.ac.id/index.php/IJEDS
International Journal of Educational Dynamics

Vol. 2 No. 1 (pp. 9-14) Desember 2019

p_ISSN 2655-4852

e_ISSN 2655-5093

learning by educators has a role, among others, to help students know the learning outcomes (learning outcomes).

Based on the assessment of learning outcomes by educators, teachers and students can get information about the strengths and weaknesses of learning and learning ${ }^{[1]}$. Assessment is one of the most important in the learning process, because the learning process is a process of changing the behavior of individuals or individuals. A process of gathering, analyzing and interpreting information to determine the level of achievement of learning goals by students is called assessment. Digital simulation learning assessment is a very important part, because this assessment teachers can assess students well. Efforts to improve the quality of education about computer competence can be achieved through improving the quality of learning and assessment of quality systems. The quality of learning can be seen from the results of the assessment. Conversely, a good grading system, will encourage teachers to determine the right strategy and motivate students to learn better.

In the case of the teacher, a good grading system can provide an overview of the quality of learning and can help in planning learning strategies. If assessed by students themselves, a good grading system can provide motivation to improve their skills. Through assessment (assessment), can obtain information that can be used in making decisions about the curriculum, programs, schools, students and other educational policies.

In authentic assessment, in addition to aspects of attitude (affective), knowledge competence (cognitive) and competency skills (psychomotor) and various instruments or test equipment used, we must also look at student input, process and output. Assessment of student learning outcomes must also be carried out at the beginning of learning (assessment input), during research (assessment process), and after learning (ranking of outputs).

It can be concluded that authentic assessment is used to assess student ability in a measurable way, but not all teachers understand how to apply authentic assessment. In the 2013 curriculum the obstacles faced by teachers in the 2013 training curriculum, namely the problem of learning assessment, where teachers still have difficulty applying the concept of 2013 curriculum assessment in the learning process, because in the 2013 


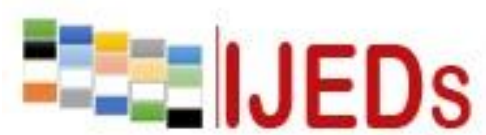

http://ijeds.ppj.unp.ac.id/index.php/IJEDS
International Journal of Educational Dynamics

Vol. 2 No. 1 (pp. 9-14) Desember 2019

p_ISSN 2655-4852

e_ISSN 2655-5093

learning curriculum assessment, teachers are asked to interpret the values written on learning activities until the end of the lesson.

\section{METHOD}

This research is a development using the design of Research and Development R \& D (research and development). Research and Development is a research model used to produce certain products, and test the effectiveness of the product. This development study is designed to produce products in the form of authentic assessment tools in digital simulation based learning inquiry in class X TKJ SMK Negeri 05 Padang. Product development research consists of five phases / stages: 1) Analysis, 2) Design, 3) Development, 4) Implementation, and 5) evaluation. The instrument used in this study is an instrument of validation, practicality of the instrument with the aim of seeing the practicality of using authentic assessment.

a. Instrument validation.

Instrument validation instruments in sheet form used to collect data regarding the validity or failure of an authentic inquiry-based assessment instrument developed. Validation is carried out by experts in the field validator. The validation sheet will be filled in by the first validator; The validation sheet contains indicators that will be assessed by the validator in the form of content suitability, feasibility of construction (presentation component) and language components. Validation is done aimed at giving ratings, suggestions, and feedback on the authentic assessment instruments developed.

\section{b. Practicality questionnaire}

Practical instruments are instruments used to gather information about authentic assessment practices developed. This instrument is a teacher response questionnaire in the practicality of authentic assessment instruments, so that researchers can find out how easy it is to use authentic learning assessments.

\section{RESULTS AND DISCUSSION}

This research was conducted in January which will be adjusted to the learning program specified in SMK N 5 Padang City in 2018/2019 academic year. Practicality data analysis was obtained from the teacher's questionnaire response instrument to the 
http://ijeds.ppj.unp.ac.id/index.php/IJEDS

product developed. The calculation of the final data value of the questionnaire results analyzed on a scale (0-100) is done using the formul.

Value Finally : $\frac{\text { score }}{\text { Score Maksimum }} x$ ideal score $(100 \%)$

Where the practicality of authentic assessment instruments can be seen in the table below:

Table 1.1. Product Rating Category

\begin{tabular}{|c|c|}
\hline Interval & Category \\
\hline $0-20$ & Very impractical \\
\hline $21-40$ & Not practical \\
\hline $41-60$ & Not practical \\
\hline $61-80$ & Practical \\
\hline $81-100$ & Very practical \\
\hline
\end{tabular}

Following is a graph explanation of practicality data obtained by the learning method using Authentic assessment instruments in Digital Simulation subjects, the practicality questionnaire was analyzed based on every aspect that exists

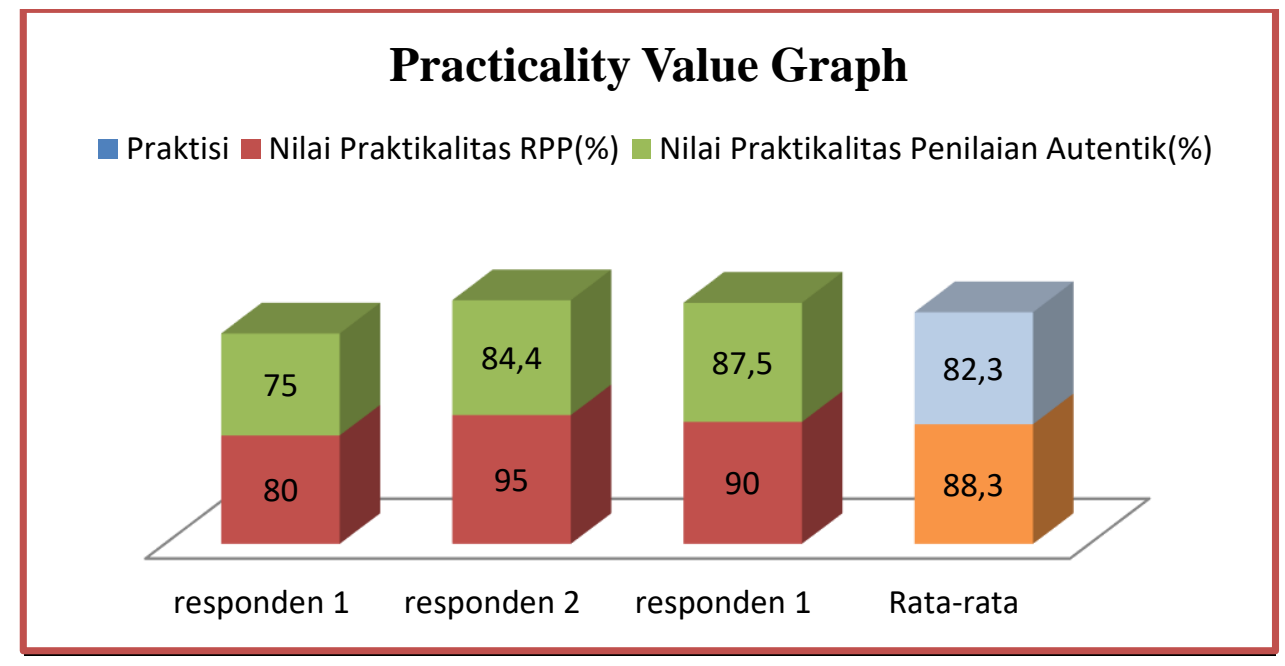

Figure 1.1. Graph of respondents' practicality assessment using Authentic assessment

In the table above it can be seen that the average value of each Authentic Assessment instrument ranges from 82.3 to 88.3 which can be categorized as very practical. Based on suggestions from Digital Simulation Teachers at SMK N 5 Kota Padang, this authentic assessment instrument can be used in everyday learning, and can be used as a guide in developing instruments on Digital Simulation material. 


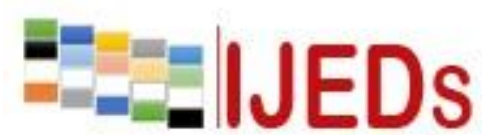

http://ijeds.ppj.unp.ac.id/index.php/IJEDS
International Journal of Educational Dynamics

Vol. 2 No. 1 (pp. 9-14) Desember 2019

p_ISSN 2655-4852

e_ISSN 2655-5093

\section{CONCLUSION}

Based on the results of the study "authentic assessment instrument development computer competence in students of SMK N 05 Padang in digital simulation study is to measure the ability of students" can be summed up as follows:

a) Authentic assessment instruments have been manufactured in Digital simulation study to measure the student's ability to use ADDIE method. Authentic assessment instrument consisting of competency assessment of attitudes, knowledge and skills competency assessment competency assessment.

b) Authentic instruments of assessment in learning Digital simulation is to measure the student's ability to meet the criteria developed valid. This is evidenced by completing stages of assessment given by expert lecturers to produce a valid assessment instrument Authentic.

c) Authentic assessment instruments in Digital simulation study is to measure the student's ability to meet the criteria developed practical. This is evidenced by the practical value given by the teacher are categorized very practical.

d) Authentic assessment instruments in Digital simulation study is to measure the student's ability to meet the criteria developed effectively. Aspect effectiveness can be seen in the results of the analysis of student learning outcomes by using time series and test-score gan. Advice can be given of the research results for further research are: Conducting in-depth studies Authentic assessment in the learning development of the Digital Simulation and learning. Instrument development by adding more pictures to illustrate some of the statements and questions are more communicative.

\section{REFERENCES}

Anas, Sudjono. 2006. Pengantar evaluasi Pendidikan, Jakarta: PT. Raja Grafindo Persada

Arikunto, S.1997. Prosedur Penilaian Suatu Pendekatan Praktek. Jakarta: Rineka Cipta Byram, H.M. \& Wenrich, R.C. (1956). Vocational Education and Practical Arts in the Community School . New York: The Macmillan Company.

B. Zul Azmi, BH Hayadi," Desain Sistem Pakar untuk Menentukan Investasi Saham Menggunakan Metode Forward Chaining," jour Adv Res. Dyn. Kontrol Syst, Vol 10, pp 1869-1873,2018. 
http://ijeds.ppj.unp.ac.id/index.php/IJEDS

Djohar, A. (2007). Pendidikan Teknologi dan Kejuruan. Dalam Ilmu dan Aplikasi Pendidikan. Bandung: Pedagogiana Press. Hal. 1285-1300.

K. Rukun,BH HAYADI, dan MS Hartawan, "Desain dan Analisis Sistem Pakar Berdasarkan Sistem Informasi untuk Mendiagnosis Kegagalan Komputer Menggunakan Metode Forward Chaining," Vol 7, pp 124-126,2018.

Kunandar, Penilaian Autentik (Penilaian Hasil Belajar Peserta Didik Berdasarkan Kurikulum 2013) Suatu pendekatan Praktis, ... hlm. 38- 39.

Peraturan Menteri Pendidikan dan Kebudayaan (Permendikbud) Republik Indonesia Nomor 66 Tahun 2013, Standar Penilaian Pendidikan, (Lampiran) Bab II tentang Standar Penilaian Pendidikan.

Peraturan Menteri Pendidikan dan Kebudayaan (Permendikbud) Republik Indonesia Nomor 104 Tahun 2014, Penilaian Hasil Belajar Oleh Pendidik pada Pendidikan Dasar dan Pendidikan Menengah, (Lampiran) tentang Pedoman Penilaian Hasil Belajar oleh Pendidik.

Pendidikan Vokasi, Jurnal Penelitian Dan Evaluasi Pendidikan, Vol.19 No 1,(46-57).

Ridwan, dan Adkon. 2009. Rumus dan Data dalam Analisis Statistik untuk Penelitian,cetakan 3, Alfabeta:Bandung. 